\title{
MARIUSZ CZUPICH
}

Katedra Integracji Europejskiej i Studiów Regionalnych

Wydział Nauk Ekonomicznych i Zarządzania

Uniwersytet Mikołaja Kopernika w Toruniu

\section{SYTUACJA BUDŻETOWA WYBRANYCH MIAST NA PRAWACH POWIATU \\ BUDGETARY SITUATION OF SELECTED CITIES WITH POWIAT RIGHTS}

Artykuł wpłynął do redakcji 31.12.2015; po recenzjach zaakceptowany 28.09.2016.

Czupich M., 2016, Sytuacja budżetowa wybranych miast na prawach powiatu, [w:] Bartosiewicz B. (red.), Potencjat rozwoju matych i średnich miast $w$ Polsce. Growth potential of small and medium-sized towns in Poland, „Space-Society-Economy”, 16, Institute of the Built Environment and Spatial Policy, Wydawnictwo Uniwersytetu Łódzkiego, Łódź, s. 29-43.

Dr Mariusz Czupich, Katedra Integracji Europejskiej i Studiów Regionalnych, Wydziat Nauk Ekonomicznych i Zarzadzania, Uniwersytet Mikołaja Kopernika w Toruniu, ul. Gagarina 13a,87-100 Toruń

e-mail: czupich@umk.pl

\section{Zarys treści}

W ostatnich latach wystąpiło szereg niekorzystnych tendencji ekonomicznych związanych z funkcjonowaniem sektora samorządowego w Polsce. Dotyczyły one m.in. spadku dochodów i wzrostu poziomu zadłużenia. Celem artykułu jest zidentyfikowanie kondycji finansowej wybranych miast na prawach powiatu. Szczególną uwagę poświęcono analizie poszczególnych typów dochodów i wydatków tych jednostek oraz dynamice ich zadłużenia. W podsumowaniu zawarto wnioski dotyczące sytuacji ekonomicznej wybranych miast.

\section{Slowa kluczowe}

Miasta na prawach powiatu, budżet samorządu terytorialnego, finanse lokalne. 


\subsection{WPROWADZENIE}

Status miast na prawach powiatu przysługuje jednostkom, które w dniu 31 grudnia 1998 roku liczyły więcej niż 100000 mieszkańców, a także miastom, które z tym dniem przestały być siedzibami wojewodów, chyba że na wniosek właściwej rady miejskiej odstąpiono od nadania miastu praw powiatu, oraz tym, którym nadano status miasta na prawach powiatu, przy dokonywaniu pierwszego podziału administracyjnego kraju na powiaty (Ustawa o samorzadzie powiatowym 1998). Potocznie miasta te są nazywane powiatami grodzkimi i ten termin znajduje się w powszechnym użyciu, jednak, co należy podkreślić, nie wynika on z zapisów ustawy. W praktyce, miasta na prawach powiatu są gminami, które mają poszerzony katalog zadań. Istotne jest również wyposażenie gminy w określone instytucje zaliczane do grup administracyjnych, społecznych czy edukacyjnych (Petryszyn 2005). W ostatnich latach miasta na prawach powiatu borykały się z wieloma problemami natury finansowej. Zaliczyć do nich można spadek dochodów własnych w strukturze dochodów spowodowany ograniczaniem działalności przez przedsiębiorstwa i w konsekwencji mniejszymi wpływami z podatków dochodowych od osób fizycznych i prawnych. W ten sposób część miast w coraz szerszy sposób uzależniała się ekonomicznie od środków z budżetu centralnego. Poza tym, problemem pozostawała niska rentowność spółek komunalnych, zwłaszcza związanych z transportem miejskim. Warto podkreślić również wysoką aktywność inwestycyjną miast spowodowaną dostępnością funduszy europejskich. Dzięki wsparciu unijnemu zrealizowano szereg przedsięwzięć infrastrukturalnych, z których wiele budzi spore kontrowersje i stanowi nieuzasadnione obciążenie dla budżetu. Wynikiem wzmożonej działalności inwestycyjnej był wzrost zadłużenia miast i w rezultacie zwiększenie wydatków związanych $\mathrm{z}$ jego obsługą. W świetle powyższych zagadnień interesującym staje się pytanie, jak wygląda kondycja finansowa miast na prawach powiatu w Polsce, a zwłaszcza tych najmniejszych, które relatywnie rzadko są przedmiotem badań, bowiem tematyka finansów samorządowych jest szeroko dyskutowana głównie w ujęciu zbiorczym (Dylewski, Filipiak, Gorzałczyńska-Koczkodaj 2007; Sierak 2011; Borodo 2015).

Celem artykułu jest ocena sytuacji budżetowej wybranych miast na prawach powiatu. Wykorzystano analizę wskaźnikową następujących elementów budżetowych: dochodów własnych z uwzględnieniem podatku dochodowego od osób prawnych (CIT) oraz fizycznych (PIT), wydatków inwestycyjnych, bieżących oraz zobowiązań finansowych. Zakres czasowy badania obejmuje lata 2005-2014, a więc zawiera okres kryzysu finansowego, który oddziaływał w znaczący sposób na warunki funkcjonowania i wpływy do budżetów miast na prawach powiatu. Biorąc pod uwagę kryterium liczby ludności, do badania wytypowano dziewięć miast: Świnoujście, Piekary Śląskie, Białą Podlaską, Tarnobrzeg, Sopot, 
Krosno, Świętochłowice, Skierniewice i Ostrołękę. Wybrano jednostki, w których w 2014 roku zameldowanych było poniżej 60 tys. mieszkańców. Są to najmniejsze spośród miast na prawach powiatu, które nie dysponują, tak dużym, jak większe miasta, potencjałem dochodowym (majątek komunalny) i kadrowym (możliwości pozyskiwania środków zewnętrznych, np. z Unii Europejskiej). Stąd też stanowią interesujące studium przypadków, zwłaszcza w zakresie zarządzania w czasach kryzysowych.

\subsection{BUDŻET POWIATU GRODZKIEGO JAKO NARZĘDZIE REALIZACJI ZADAŃ PUBLICZNYCH}

Rola sektora samorządowego w Polsce zmieniła się na przestrzeni ostatnich kilkudziesięciu lat diametralnie. Po wprowadzeniu ustroju rynkowego, sektor ten stał się realnym kreatorem rozwoju lokalnego i regionalnego. Zyskał przede wszystkim autonomię w podejmowaniu decyzji w zakresie gospodarki finansowej. Szczególne miejsce w kształtowaniu polityki lokalnej przypada miastom na prawach powiatu (potocznie nazywanym powiatami grodzkimi). Są one współcześnie jednym z najbardziej znaczących usługodawców oraz inwestorów publicznych.

Realizacja zadań publicznych jest uzależniona od wielkości uzyskiwanych dochodów. W miastach na prawach powiatu wykonywany jest szeroki zakres obowiązków, co wynika z łączenia funkcji samorządu gminnego i powiatowego. $\mathrm{W}$ związku z tym, powiatom grodzkim przysługują dochody przewidziane dla obu szczebli. Są to więc dochody własne oraz uzupełniające w postaci transferów z budżetu państwa lub budżetów innych podmiotów (np. funduszy celowych). Wśród dochodów własnych możemy wyróżnić:

- podatki komunalne przekazywane ustawowo do dyspozycji samorządów (np. podatek od nieruchomości, leśny, rolny);

- udziały w podatku dochodowym od osób fizycznych i prawnych;

- opłaty (np. opłata eksploatacyjna, targowa, miejscowa);

- dochody majątkowe, czyli osiągane przez samorząd poprzez wykorzystanie jako właściciela - należącego do niego mienia. Samorząd może składniki swojego mienia wynająć, wydzierżawić, sprzedać, oddać w wieczyste użytkowanie, wnieść jako udział lub wkład do spółki lub spółdzielni. Zatem dochodami majątkowymi będą w szczególności czynsze, opłaty za wieczyste użytkowanie gruntów, zyski spółek komunalnych (Borodo 2011, s. 91-93).

System dochodów miast na prawach powiatu jest rozbudowany i skomplikowany, co wynika z faktu, że część wpływów jest charakterystyczna dla gminy, a część dla powiatu. Stąd też postuluje się stworzenie zupełnie odrębnego, samodzielnego systemu dochodów dla powiatów ziemskich i grodzkich (zob. Borodo 2015). 
Przypisane powiatom źródła dochodowe są wyrazem samorządności finansowej i powinny spełniać określone warunki. Przede wszystkim powinny cechować się wydajnością, aby miasta mogły wykonywać przewidziane dla siebie zadania. Ponadto, ważne by sprzyjały rozwijaniu aktywności władz i nie ograniczały ich samodzielności. Biorąc pod uwagę katalog dochodów miast na prawach powiatu należy stwierdzić, że samorządy te narażone są na dużą niepewność. Skoro część wpływów jest związana z aktywnością przedsiębiorstw i sytuacją na rynku pracy, to możliwości oddziaływania samorządu są w tej kwestii bardzo ograniczone. Wiele zależy za to od polityki gospodarczej państwa czy koniunktury na rynkach światowych. Wynika stąd wniosek, że organy powiatów grodzkich mają utrudnione zadanie $\mathrm{w}$ zakresie planowania i realizacji polityki rozwojowej na swoim obszarze. Jedną z możliwości wypełnienia luki kapitałowej jest korzystanie ze zwrotnych źródeł finansowania.

W skład długu jednostek samorządowych wlicza się zaciągnięte kredyty i pożyczki, wyemitowane papiery wartościowe, przyjęte depozyty oraz wymagalne zobowiązania. Co więcej, w zakres pojęcia kredytów i pożyczek należy również dodać:

- umowy o partnerstwie publiczno-prywatnym, które mają wpływ na poziom długu publicznego;

- papiery wartościowe, których zbywalność jest ograniczona;

- umowy sprzedaży, w których cena jest płatna w ratach;

- umowy leasingu zawarte z producentem lub finansującym, w których ryzyko i korzyści z tytułu własności są przeniesione na korzystającego z rzeczy;

- umowy nienazwane o terminie zapłaty dłuższym niż rok, związane z finansowaniem usług, dostaw, robót budowlanych, które wywołują skutki ekonomiczne podobne do umowy pożyczki lub kredytu (Korolewska, Marchewka, Bartkowiak 2011, s. 100-101).

Z powyższego wynika, że istnieje wiele możliwości pozyskania kapitału i realizacji przedsięwzięć, w tym inwestycji. Należy podkreślić, że zaciąganie zobowiązań nie musi oznaczać trudnej sytuacji dla samorządu. Jest to instrument gospodarki finansowej szeroko wykorzystywany na całym świecie. Poza tym dług, który powstał wskutek realizacji zadań inwestycyjnych można określić jako dług opłacalny, jeżeli sfinansowane przedsięwzięcie jest źródłem dochodów umożliwiających spłatę rat i odsetek (Borodo 2006, s. 218). Z drugiej strony, regulacja prawna pułapów zadłużenia jest potrzebna, ponieważ chroni interesy społeczności lokalnej (Młynarczyk 2012, s. 46). Wynika to stąd, że zbyt duże obciążenie budżetu spłatą rat i odsetek może powodować potrzebę redukcji wydatków bieżących i tym samym obniżenia sposobu zaspokajania potrzeb wspólnoty mieszkańców. 


\subsection{DOCHODY WYBRANYCH MIAST NA PRAWACH POWIATU}

Biorąc pod uwagę wyniki budżetowe wytypowanych miast należy stwierdzić, że nie odbiegały one od ogólnych tendencji wszystkich miast na prawach powiatu, wśród których w 2014 roku tylko 17 uzyskało nadwyżkę dochodów nad wydatkami. W badanych miastach dodatni wynik finansowy uzyskano tylko w Świnoujściu, Piekarach Śląskich oraz Białej Podlaskiej (tab. 1). Ciekawostką jest fakt, że najwyższe dochody uzyskał najmniejszy w analizowanym gronie Sopot - ponad $267 \mathrm{mln}$ zł. Z kolei najwyższe wydatki były udziałem Krosna (303 mln zł). Najgorszy wynik finansowy odnotowały za to Świętochłowice, Skierniewice oraz Ostrołęka, których deficyt budżetowy oscylował wokół 9-11\% (przy średniej dla wszystkich miast na prawach powiatu na poziomie 3,2\%).

Tabela 1

Dochody i wydatki wybranych miast na prawach powiatu w 2014 roku

\begin{tabular}{|c|c|c|c|c|c|}
\hline $\begin{array}{c}\text { Miasto } \\
\text { (województwo) }\end{array}$ & $\begin{array}{c}\text { Ludność } \\
\text { (w tys.) } \\
\text { stan na } \\
31.12 .2014\end{array}$ & $\begin{array}{l}\text { Dochody } \\
\text { (w mln zł) }\end{array}$ & $\begin{array}{l}\text { Wydatki } \\
\text { (w mln zf) }\end{array}$ & $\begin{array}{c}\text { Wynik } \\
\text { budżetowy } \\
\text { (w mln zł) }\end{array}$ & $\begin{array}{l}\text { Deficyt } \\
\text { dochodów } \\
\text { (w \%) }\end{array}$ \\
\hline $\begin{array}{l}\text { Świnoujście } \\
\text { (zachodniopom.) }\end{array}$ & 41,3 & 245,0 & 231,7 & 13,3 & - \\
\hline $\begin{array}{l}\text { Piekary Śląskie } \\
\text { (śląskie) }\end{array}$ & 57,1 & 200,1 & 187,0 & 13,1 & - \\
\hline $\begin{array}{l}\text { Biała Podlaska } \\
\text { (lubelskie) }\end{array}$ & 57,6 & 231,7 & 220,7 & 11,0 & - \\
\hline $\begin{array}{l}\text { Tarnobrzeg } \\
\text { (podkarpackie) }\end{array}$ & 48,2 & 237,1 & 237,8 & $-0,7$ & 0,3 \\
\hline $\begin{array}{l}\text { Sopot } \\
\text { (pomorskie) }\end{array}$ & 37,9 & 267,2 & 276,1 & $-8,9$ & 3,3 \\
\hline $\begin{array}{l}\text { Krosno } \\
\text { (podkarpackie) }\end{array}$ & 47,2 & 293,0 & 303,0 & $-10,0$ & 3,4 \\
\hline $\begin{array}{l}\text { Świętochłowice } \\
\text { (śląskie) }\end{array}$ & 51,8 & 189,9 & 206,3 & $-16,4$ & 8,6 \\
\hline $\begin{array}{l}\text { Skierniewice } \\
\text { (łódzkie) }\end{array}$ & 48,6 & 194,9 & 212,0 & $-17,1$ & 8,8 \\
\hline $\begin{array}{l}\text { Ostrołęka } \\
\text { (mazowieckie) }\end{array}$ & 52,9 & 266,3 & 294,4 & $-28,1$ & 10,6 \\
\hline
\end{tabular}

Źródło: GUS 2015, s. 17-27; Krajowa Rada Regionalnych Izb Obrachunkowych 2015, s. 207-208. 
Analizy budżetów w jednym roku nie pozwalają na wyciągnięcie głębszych wniosków w zakresie prowadzonej gospodarki finansowej. Stąd, w badaniu dochodów wzięto pod uwagę trzy okresy: 2005-2008, 2009-2011 i 2012-2014 (rys. 1).

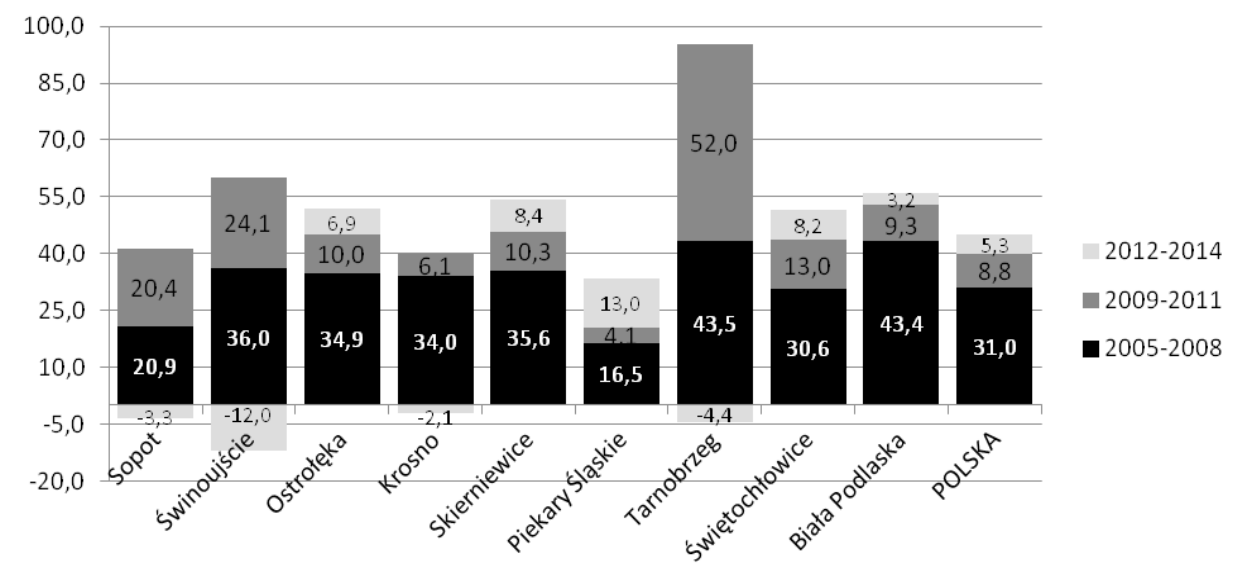

Rys. 1. Zmiany dochodów własnych na 1 mieszkańca w wybranych miastach na prawach powiatu w latach 2005-2014 (w \%)

Uwaga: słupek POLSKA prezentuje średnie wartości dla wszystkich miast na prawach powiatu

Źródło: opracowanie własne na podstawie: Krajowa Rada Regionalnych Izb Obrachunkowych 2006, 2009, 2010, 2012, 2013, 2015

Okazuje się, że dochody własne na 1 mieszkańca w analizowanych miastach najszybciej rosły w latach 2005-2008. Największe przyrosty dochodów odnotował Tarnobrzeg (o 43,5\%) oraz Biała Podlaska (43,4\%). Jedynie Świętochłowice, Sopot i Piekary Śląskie zrealizowały niższy wzrost dochodów niż średnio wszystkie miasta na prawach powiatu. W latach 2009-2011 w polskich miastach miał miejsce o wiele skromniejszy wzrost dochodów (o 8,8\%). Na uwagę zasługuje Tarnobrzeg, który w analizowanym okresie zdołał bardzo znacząco poprawić wpływy budżetowe. Pozostałe miasta, oprócz Krosna i Piekar Śląskich, odnotowały wzrosty wyższe od średniej dla wszystkich miast na prawach powiatu. Kolejny okres 2012-2014 to czas, kiedy dotychczasowy lider - Tarnobrzeg oraz Sopot, Krosno i Świnoujście zmniejszyły swoje wpływy budżetowe. Warto podkreślić, że największy spadek był udziałem Świnoujścia, gdzie o 12\% zmniejszyły się dochody $\mathrm{w}$ przeliczeniu na 1 mieszkańca. W pozostałych miastach, z wyjątkiem Białej Podlaskiej, notowano większe przyrosty dochodów niż średnio w kraju. Warto podkreślić, że sytuacja Świnoujścia w najbliższych latach ulegnie znaczącej poprawie. Związane jest to $\mathrm{z}$ największą instalacją regazyfikacyjną w basenie Morza Bałtyckiego, a mianowicie terminalem LNG, który w 2016 roku 
zostanie oddany do użytku właśnie w tym mieście. Władze miasta szacują, że po planowanej rozbudowie terminala, $\mathrm{z}$ tytułu podatku od nieruchomości co roku wpływać będzie ok. $50 \mathrm{mln}$ zł, a więc równowartość rocznych wydatków inwestycyjnych (Gazeta Prawna 2015). Z kolei Sopot, chociaż w ostatnim analizowanym okresie zmniejszył swoje dochody o $3,3 \%$, jest jednym z najbogatszych miast w Polsce. W 2005 roku dochody własne na 1 mieszkańca były tam dwukrotnie wyższe niż średnia w kraju, a w 2014 roku przewyższały ten poziom o 60\% (Krajowa Rada Regionalnych Izb Obrachunkowych 2006, 2015). Przyczyną takiego stanu rzeczy jest wysoka przedsiębiorczość Sopocian. Liczba zarejestrowanych podmiotów gospodarczych (ok. 7500) w przeliczeniu na 1 mieszkańca jest najwyższa wśród wszystkich miast w Polsce. Dominujące branże gospodarcze pod względem liczby przedsiębiorstw to obsługa nieruchomości i firm oraz handel. Stopa bezrobocia na początku drugiej dekady lat 2000. oscylowala wokół 4-5\%. Ponadto, na wysokie dochody wpływał również fakt, że miasto ma status uzdrowiska, co w połączeniu z jego nadmorskim położeniem sprawia, że jest atrakcyjnym miejscem wypoczynku i rehabilitacji. Znajduje to swoje odzwierciedlenie w rozwoju usług turystycznych (Sopot zajmuje 11 miejsce spośród 66 miast na prawach powiatu pod względem liczby turystycznych obiektów noclegowych). Wszystko to sprawia, że ok. $30-40 \%$ dochodów miasta stanowią wpływy z podatku dochodowego od osób fizycznych i prawnych. Biorąc pod uwagę dynamikę wzrostu całości dochodów z podatku PIT i CIT w latach 2005-2014 okazuje się, że w Sopocie była ona umiarkowana w porównaniu z pozostałymi badanymi miastami (rys. 2).

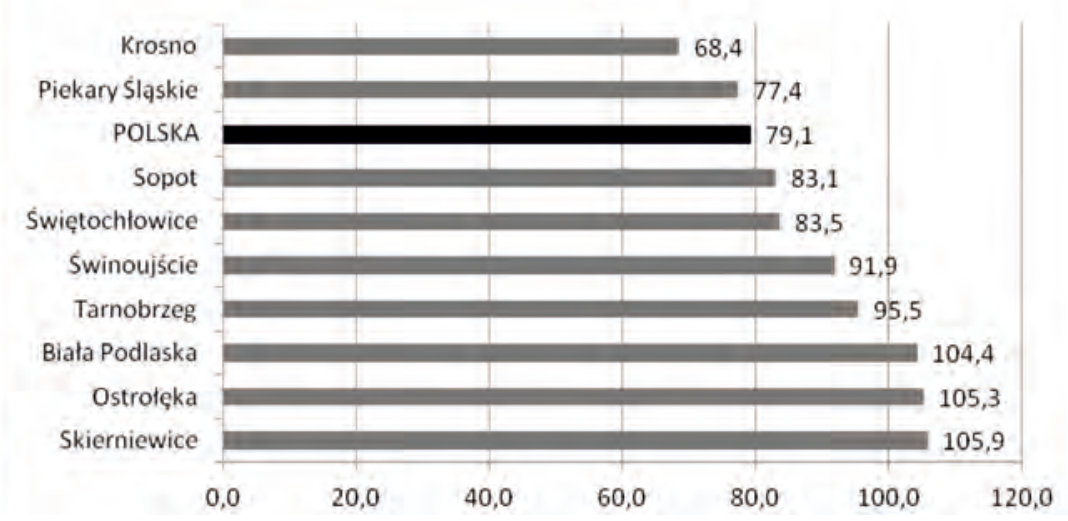

Rys. 2. Zmiany dochodów z PIT i CIT na 1 mieszkańca w wybranych miastach na prawach powiatu w latach 2005-2014 (w \%)

Uwaga: jak w rys. 1

Źródło: opracowanie własne na podstawie: Krajowa Rada Regionalnych

Izb Obrachunkowych 2006, 2009, 2012, 2015 
Wpływy z PIT i CIT są często utożsamiane z efektywnością zarządzania danym miastem. Chodzi tutaj o rezultaty polityki rozwoju jednostki terytorialnej związane z pozyskiwaniem inwestorów i tworzeniem warunków do rozwoju przedsiębiorczości. Wspomniany Sopot przewodził w zakresie wysokości pozyskiwanych podatków w przeliczeniu na 1 mieszkańca. W 2005 roku było to 1076 zł w porównaniu do 670 zł średniej krajowej, natomiast w 2014 roku - 1970 zł w stosunku do 1200 zł w kraju (Krajowa Rada Regionalnych Izb Obrachunkowych 2006, 2015). W pozostałych badanych miastach, chociaż dochody te były niższe od średnich w kraju, to z wyjątkiem Krosna i Piekar Śląskich rosły znacznie szybciej niż przeciętne. Na wyróżnienie zasłużyły Biała Podlaska, Ostrołęka i Skierniewice, których wpływy z PIT i CIT w okresie 2005-2014 wzrosły o ponad $100 \%$. W przypadku Ostrołęki wpływ na taką sytuację miał przemysł energetyczny oraz celulozowo-papierniczy, który odgrywa znaczącą rolę w gospodarce regionu. Z kolei zaletą Skierniewic jest bliskie położenie względem dwóch dużych miast - Warszawy i Łodzi i względnie niskie ceny nieruchomości. Stwarza to dogodne warunki do zamieszkiwania w tym mieście i dojazdów do pracy w metropoliach.

\subsection{WYDATKI I ZADLUŻENIE WYBRANYCH MIAST NA PRAWACH POWIATU}

Wysokość wydatków inwestycyjnych przypadająca na 1 mieszkańca w poszczególnych miastach w latach 2005-2014 różniła się dość znacznie. Na czele tego zestawienia były niezmiennie Świnoujście, Sopot, Krosno i Tarnobrzeg (rys. 3).

Świadczy to o tym, że wysokość wydatków w danym roku nie wynikała z jednorazowych przedsięwzięć, lecz była związana z realizacją długofalowej strategii inwestycyjnej. W przypadku Sopotu i Świnoujścia część inwestycji była związana z rozbudową infrastruktury turystycznej. Należy podkreślić, że w pierwszym $\mathrm{z}$ tych miast w 2008 roku wydatki inwestycyjne na 1 mieszkańca były 5-krotnie wyższe, a w 2011 roku ponad 3-krotnie wyższe niż wynosiła średnia dla ogółu miast na prawach powiatu.

W strukturze sektorowej wydatków inwestycyjnych miast na prawach powiatu dominuje od kilku lat transport. W 2000 roku ok. 30\%, natomiast w 2013 roku ok. 47\% wszystkich wydatków była przeznaczona właśnie na ten dział (Ranking... 2014, s. 4). Obejmuje on m.in. remonty i budowę dróg zarządzanych przez miasta oraz zakup taboru transportowego. Na drugim miejscu znajdowała się gospodarka komunalna (ponad 31\% w 2000 roku i ok. 8\% wszystkich wydatków w 2013 roku), a więc przedsięwzięcia ukierunkowane na modernizację i remonty sieci ciepłowniczych, wodno-kanalizacyjnych, oczyszczanie miasta czy oświetlenie ulic. Należy podkreślić, że malejący udział gospodarki komunalnej w inwestycjach miast na prawach powiatu wynika z przekształceń zakładów budżetowych w spółki prawa handlowego, których to działalność nie została uwzględnio- 


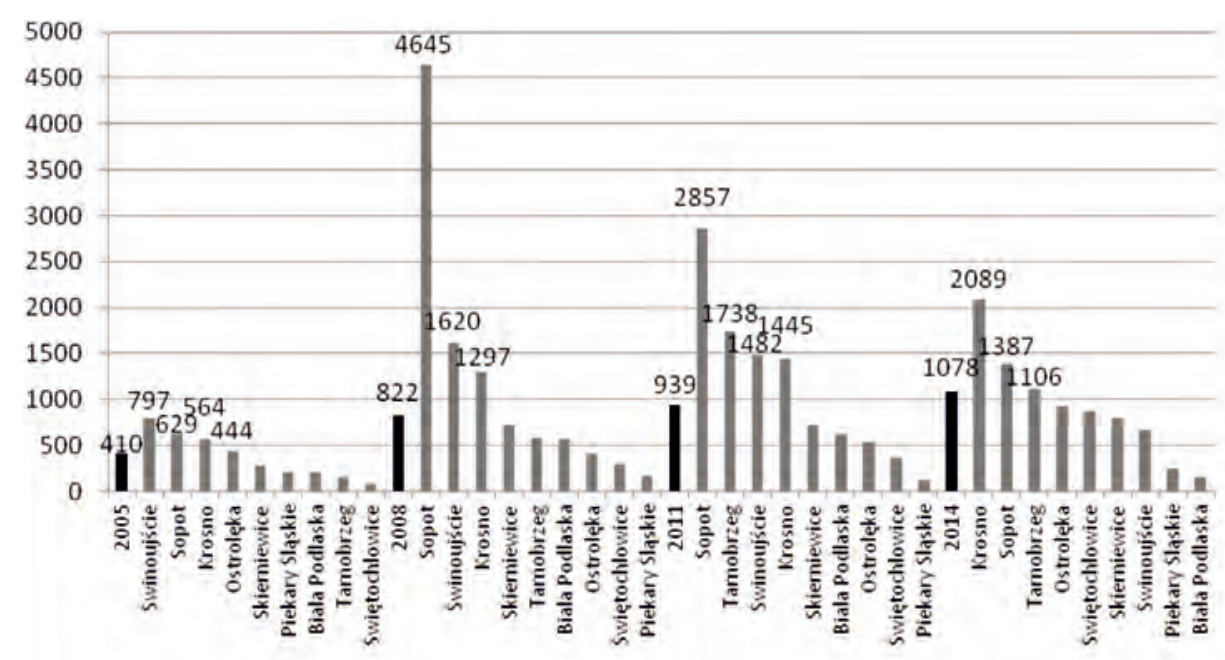

Rys. 3. Wydatki inwestycyjne na 1 mieszkańca w wybranych miastach na prawach powiatu w latach 2005-2014 (w zł)

Uwaga: czarne słupki z oznaczeniem lat: 2005, 2008, 2011 i 2014 przedstawiają średnie wartości dla wszystkich miast na prawach powiatu

Źródło: opracowanie własne na podstawie: Krajowa Rada Regionalnych Izb Obrachunkowych 2006, 2009, 2012, 2015

na. $\mathrm{Na}$ ostatnim miejscu wśród inwestycji miejskich znalazła się administracja (3\% w 2000 i 4,3\% w 2013 roku). Wynika stąd, że działania władz miejskich były ukierunkowane głównie na przebudowę i modernizację infrastruktury twardej (tj. dróg, budynków, sieci wodno-kanalizacyjnych), co wynikało z chęci nadrobienia wieloletnich zaniedbań w tej dziedzinie. Wartość inwestycji w e-administrację czy poprawę dostępności usług poszczególnych urzędów była znacząco mniejsza ${ }^{1}$.

${ }^{1}$ Należy przy tym pamiętać, że inwestycje infrastrukturalne pochłaniają o wiele wyższe kwoty niż pozostałe działania, stąd też przedsięwzięcia administracyjne znalazły się w omawianym zestawieniu na ostatnim miejscu. Nie zmienia to jednak faktu, że wielu polskim miastom obca jest koncepcja tzw. miasta inteligentnego (ang. smart city), która zakłada wdrożenie różnego rodzaju innowacyjnych rozwiązań w obszarze transportu, gospodarki odpadami, energetyki czy jakości życia mieszkańców. Mają one przyczynić się do podniesienia sprawności zarządzania miastem, obniżenia kosztów jego funkcjonowania oraz wzrostu jakości życia mieszkańców. Przykładem innowacyjnego podejścia w sferze administracji jest Barcelona, gdzie zainstalowano w różnych punktach miasta kioski z odpowiednimi aplikacjami zapewniające mieszkańcom możliwość realizacji czynności administracyjnych on-line. Utworzono także portal umożliwiający zgłaszanie przez mieszkańców rozwiązań i pomysłów na rzecz poprawy jakości życia w mieście, a także udostępniono bezpłatną aplikację na telefon, która umożliwia obywatelom komunikację z przedstawicielami miasta. Mogą oni w ten sposób wyrażać swoje opinie, oceniać politykę miejską i angażować się w różne procesy w mieście (http://smartcity.ben.cat/en/barcelona-open-government.html - dostęp: 12.10.2015). 
Innym rodzajem wydatków lokalnych są wydatki bieżące. Obejmują one m.in. wynagrodzenia pracowników jednostek samorządu terytorialnego oraz zakup towarów i usług na potrzeby funkcjonowania administracji. Wydatki te w przeliczeniu na 1 mieszkańca informują o kosztach funkcjonowania całej administracji miejskiej oraz pomocy społecznej, oświaty itd.

Za wyjątkiem Sopotu, w grupie analizowanych miast na prawach powiatu wzrost wydatków w latach 2005-2014 był niższy niż przeciętny we wszystkich miastach powiatowych (rys. 4). W najmniejszym stopniu wydatki bieżące wzrosły w Krośnie (61,3\%), Piekarach Śląskich (67,6\%) oraz Świnoujściu (72,9\%). Na drugim biegunie znalazł się wspomniany Sopot, który nieznacznie przekroczył średnią dla Polski. W mieście tym wydatki bieżące wzrosły o ponad $100 \%$, co jest konsekwencją m.in. większych kosztów administracyjnych wynikających m.in. ze wzrostu zatrudnienia.

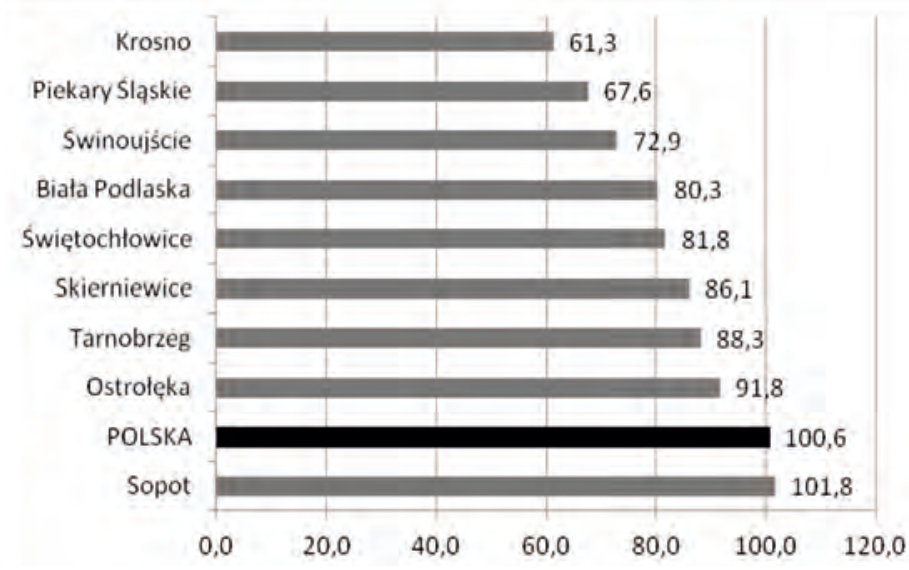

Rys. 4. Zmiany wydatków bieżących na 1 mieszkańca w wybranych miastach na prawach powiatu w latach 2005-2014 (w \%)

Uwaga: jak w rys. 1

Źródło: opracowanie własne na podstawie: Krajowa Rada Regionalnych Izb Obrachunkowych 2006, 2009, 2012, 2015

Wzrost ogółu wydatków miejskich, a zwłaszcza związanych z inwestycjami infrastrukturalnymi spowodował gwałtowny przyrost zadłużenia. Wszystkie miasta na prawach powiatu w latach 2005-2014 powiększyły je o 18,7 mld zł (tab. 2).

Spośród analizowanego grona, najmniejszy wzrost długu wystąpił w Piekarach Śląskich (o 25,3 mln zł) oraz Świętochłowicach i Białej Podlaskiej (45 mln zł). Z kolei najbardziej dynamiczny jego wzrost odnotowano w Tarnobrzegu, Krośnie i Sopocie (odpowiednio: o 84,1, 87,2 i 94,7 mln zł). Biorąc pod uwagę kwotę bazową zadłużenia w 2005 roku należy zwrócić uwagę także na Skierniewice, które 
Tabela 2

Zobowiązania finansowe wybranych miast na prawach powiatu w latach 2005-2014 (w mln zł)

\begin{tabular}{|l|c|r|r|r|c|}
\hline \multicolumn{1}{|c|}{ Miasta } & 2005 & 2008 & 2011 & 2014 & $\begin{array}{c}\text { Wzrost } \\
\text { W latach } \\
\text { 2005-2014 }\end{array}$ \\
\hline Piekary Śląskie & 18,3 & 29,7 & 61,0 & 43,6 & 25,3 \\
\hline Świętochłowice & 25,1 & 27,2 & 51,1 & 70,1 & 45,0 \\
\hline Skierniewice & 13,8 & 12,5 & 56,4 & 73,1 & 59,3 \\
\hline Biała Podlaska & 47,4 & 67,4 & 123,3 & 92,5 & 45,1 \\
\hline Ostrołęka & 39,0 & 28,2 & 58,4 & 107,7 & 68,7 \\
\hline Świnoujście & 54,9 & 51,0 & 73,6 & 113,2 & 58,3 \\
\hline Sopot & 21,3 & 7,8 & 119,9 & 116,0 & 94,7 \\
\hline Tarnobrzeg & 37,5 & 49,1 & 103,4 & 121,6 & 84,1 \\
\hline Krosno & 35,8 & 55,2 & 94,9 & 123,0 & 87,2 \\
\hline POLSKA* & 7643 & 10514 & 22108 & 26408 & 18765 \\
\hline
\end{tabular}

* Zobowiązania finansowe wszystkich miast na prawach powiatu.

Źródło: opracowanie własne na podstawie: Krajowa Rada Regionalnych Izb Obrachunkowych 2006, 2009, 2012, 2015.

powiększyły swoje zadłużenie ponad 5-krotnie (rys. 5). Można zatem stwierdzić, że miasta, które wykazywały się dużą aktywnością inwestycyjną finansowały ją ze zwrotnych źródeł finansowania. W wymienionych miastach były to głównie kredyty i pożyczki.

W świetle powyższych rozważań powstaje pytanie, czy wzrost zadłużenia spowodował przekroczenie dopuszczalnych limitów ${ }^{2}$.

${ }^{2}$ Ograniczenia długu samorządowego wynikają z przepisów zawartych w ustawie o finansach publicznych. Do końca 2013 roku obowiązywały dwa: 60\% limit relacji łącznej kwoty długu do dochodów budżetowych oraz 15\% limit relacji planowanych spłat kredytów, pożyczek i wykupu obligacji wraz z odsetkami i dyskontem w danym roku budżetowym do dochodów budżetowych. Począwszy od 2014 roku obowiązuje nowy sposób obliczania dopuszczalnego limitu zadłużenia. Opiera się on na indywidualnym wskaźniku zadłużenia (IWZ). IWZ stanowi, że w danym roku budżetowym wartość spłaty zobowiązań wraz z kosztami ich obsługi do dochodów ogółem budżetu jednostki samorządu terytorialnego nie może przekroczyć średniej arytmetycznej z obliczonych dla ostatnich trzech lat relacji jej dochodów bieżących, powiększonych o dochody ze sprzedaży majątku oraz pomniejszonych o wydatki bieżące do dochodów ogółem budżetu. Zob.: Ustawa z dnia 27 sierpnia 2009 r. o finansach publicznych (Dz. U., 2013, poz. 885 z późn. zm.), art. 243. Ze względu na fakt, że w artykule zestawione są dane z lat 2005, 2008, 2011 i 2014 zdecydowano, że dalsza analiza zadłużenia będzie odbywać się w odniesieniu do $60 \%$ limitu relacji długu do dochodów budżetowych. 


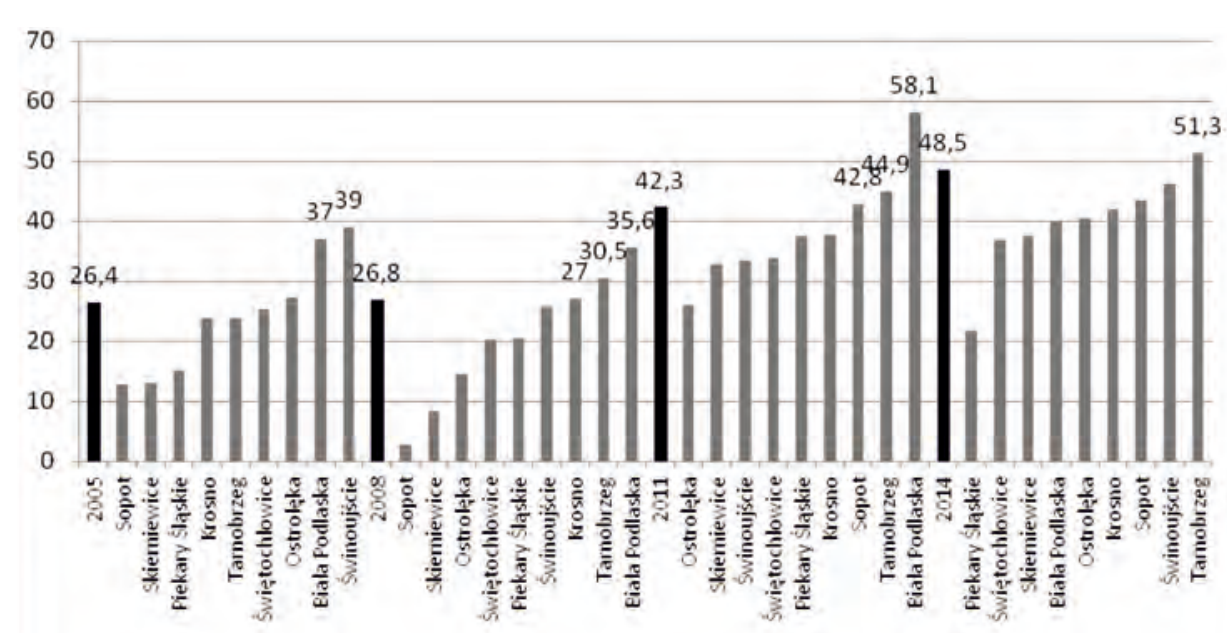

Rys. 5. Zobowiązania finansowe wybranych miast na prawach powiatu w latach 2005-2014 (w \% dochodów)

Uwaga: jak w rys. 3

Źródło: opracowanie własne na podstawie: Krajowa Rada Regionalnych Izb Obrachunkowych 2006, 2009, 2012, 2015

$\mathrm{Z}$ danych rys. 5 wynika, że żadne z analizowanych miast, pomimo znacznego wzrostu zobowiązań, nie przekroczyło dopuszczalnego limitu zadłużenia. Najbliżej tej granicy była Biała Podlaska w 2011 roku, jednak w następnych latach zdołała zredukować dług do ok. $40 \%$ dochodów. Warto zwrócić uwagę na fakt, że tylko w sporadycznych przypadkach analizowane miasta przekraczały średnie zadłużenie dla miast na prawach powiatu. W 2005 roku były to dwa miasta - Biała Podlaska i Świnoujście, w 2008 i 2011 roku - trzy miasta (Tarnobrzeg, Krosno i Biała Podlaska w 2008 roku i Tarnobrzeg, Sopot, Biała Podlaska w 2011 roku), zaś w 2014 roku już tylko jedno - Tarnobrzeg, którego dług przekroczył nieznacznie granicę połowy dochodów. Wydaje się więc, że zadłużenie badanych miast na prawach powiatu jest w bezpiecznych granicach i nie stanowi zagrożenia dla przekroczenia przepisów ustawowych. Większe problemy mogą mieć duże miasta na prawach powiatu, które zadłużają się w szybszym tempie niż analizowane jednostki. Spowodowane jest to potrzebami inwestycyjnymi na większą skalę.

Sytuacja finansowa polskich miast znajduje odzwierciedlenie w całym sektorze finansów publicznych, który w latach 2009-2014 zwiększył swoje zobowiązania o ok. 25\% (tab. 3). Dostępność środków europejskich oraz największy po 1989 roku boom inwestycyjny spowodował, że dług samorządowy przyrastał także bardzo szybko: z ponad 39 mld zł w 2009 roku do ok. 72 mld zł w roku 
$2014^{3}$. Obok miast na prawach powiatu również pozostałe samorządy często korzystały ze zwrotnych źródeł finansowania. W efekcie udział miast w długu samorządowym pozostawał niemal na niezmienionym poziomie ok. $37 \%$.

Tabela 3

Zadłużenie całego sektora finansów publicznych a zadłużenie sektora samorządowego z uwzględnieniem miast na prawach powiatu

\begin{tabular}{|l|r|r|r|r|r|r|r|}
\hline \multicolumn{1}{|c|}{ Wyszczególnienie } & 2009 & 2010 & 2011 & 2012 & 2013 & 2014 \\
\hline \multicolumn{7}{|c|}{ Zadłużenie (w mld zł) } \\
\hline $\begin{array}{l}\text { Sektora finansów } \\
\text { publicznych }\end{array}$ & 669,8 & 747,8 & 815,3 & 840,4 & 882,2 & 826,7 \\
\hline Sektora samorządowego & 39,3 & 53,5 & 64,2 & 67,3 & 68,3 & 71,6 \\
\hline $\begin{array}{l}\text { w tym miast na } \\
\text { prawach powiatu }\end{array}$ & 14,7 & 18,1 & 22,1 & 23,8 & 24,9 & 26,4 \\
\hline $\begin{array}{l}\text { Miast na prawach } \\
\text { powiatu do długu } \\
\text { samorządowego }\end{array}$ & 37,4 & 33,8 & 34,4 & 35,4 & 36,5 & 36,9 \\
\hline $\begin{array}{l}\text { Sektora samorządowego } \\
\text { ogółem do zadłużenia } \\
\text { całego sektora finansów } \\
\text { publicznych }\end{array}$ & 5,9 & 7,2 & 7,9 & 8,0 & 7,7 & 8,7 \\
\hline
\end{tabular}

Źródło: obliczenia własne na podstawie danych Ministerstwa Finansów 2015; Krajowa Rada Regionalnych Izb Obrachunkowych, 2010, 2011, 2012, 2013, 2014, 2015.

Wydaje się, że problemem polskich samorządów jest nie wielkość zadłużenia, bowiem jego udział w całym sektorze finansów publicznych wahał się między $5,9 \%$ a $8,7 \%$, a szybki przyrost. Stawia to pod znakiem zapytania możliwość korzystania z funduszy europejskich w perspektywie finansowej 2014-2020 oraz ogranicza zdolności rozwojowe w dłuższym horyzoncie czasowym. Należy podkreślić, że wszystkie miasta na prawach powiatu chociaż partycypują w długu samorządowym nie obciążają go w znaczący sposób.

${ }^{3}$ Jako przyczynę rosnącego długu samorządowego, oprócz zwiększenia inwestycji współfinansowanych ze środków europejskich i spadku dochodów własnych wskutek kryzysu finansowego, wymienia się także mobilizację podmiotów samorządowych do zadłużania się na zasadach obowiązujących do końca 2013 roku w obawie przed formalną utratą zdolności kredytowej w obliczu nowych zasad wyznaczających limity zadłużenia (Poniatowicz i in. 2010, s. 38). 


\subsection{WNIOSKI}

Kryzys finansowy, który wybuchł pod koniec pierwszej dekady lat 2000. przyniósł negatywne konsekwencje dla funkcjonowania przedsiębiorstw, a w rezultacie budżetów samorządowych. Niemniej jednak, wpływ ten w badanych miastach na prawach powiatu wydawał się bardzo ograniczony. Potwierdza to fakt, że w większości analizowanych miast w latach 2005-2014 nastąpił większy wzrost dochodów własnych niż przeciętnie w kraju. Dodatkowym pozytywnym aspektem był również wzrost wpływów z podatku dochodowego od osób fizycznych i prawnych, który ma duże znaczenie wśród źródeł dochodów własnych. Po stronie wydatkowej budżetu warto podkreślić niższy przyrost wydatków bieżących od średnich w kraju oraz dużą aktywność inwestycyjną zwłaszcza w sferze transportu i gospodarki komunalnej. Na szczególną uwagę zasłużyły Krosno, Sopot, Tarnobrzeg i Świnoujście, które w badanym okresie notowały wyższe wydatki inwestycyjne na mieszkańca niż średnia dla wszystkich miast na prawach powiatu.

W rezultacie, całość prowadzonej gospodarki budżetowej w wybranych miastach należy uznać za ostrożną i racjonalną. Kwoty zobowiązań względem dochodów znajdują się w bezpiecznych przedziałach (nie przekraczają ustawowych limitów), co umożliwia prowadzenie dalszej polityki rozwojowej w oparciu o realizację przedsięwzięć inwestycyjnych.

\section{LITERATURA}

Borodo A., 2006, Samorzad terytorialny. System prawno-finansowy, Wydawnictwo Lexis Nexis Polska, Warszawa, s. 218.

Borodo A., 2011, System finansowy samorzadu terytorialnego w Polsce, Wydawnictwo Dom Organizatora, Toruń, s. 91-93.

Borodo A., 2015, Zagadnienia prawne systemu dochodów samorzadu powiatowego i propozycje jego reformy, „Prawo Budżetowe Państwa i Samorządu”, 2(3), s. 9-21.

Dylewski M., Filipiak B., Gorzałczyńska-Koczkodaj M., 2007, Finanse samorzadowe: narzędzia, decyzje, procesy, PWN, Warszawa.

Gazeta Prawna, http://podatki.gazetaprawna.pl/artykuly/910688,swinoujscie-podatek-odgazoportu.html (dostęp: 11.12.2015).

Korolewska M., Marchewka K., Bartkowiak K., 2011, Zadlużenie samorządów terytorialnych w Polsce, „Studia BAS”, 4(28), s. 100-101.

Ministerstwo Finansów, http://www.finanse.mf.gov.pl/dlug-publiczny/publikacje/raportyroczne (dostęp: 17.10.2015).

Młynarczyk A., 2012, Zadhużenie jednostek samorzadu terytorialnego a państwowy dhug publiczny, ,Finanse Komunalne”, 1-2 (156-157), s. 46.

Petryszyn J., 2005, Instytucyjne podstawy ośrodków centralnych poziomu powiatowego w Polsce, Uniwersytet Śląski, Sosnowiec. 
Poniatowicz M., Salachna J., Perło D., 2010, Efektywne zarzadzanie dtugiem w jednostce samorzadu terytorialnego, Wolters Kluwer Polska, Warszawa, s. 38.

Powierzchnia i ludność w przekroju regionalnym w 2015 r., 2015, GUS, Warszawa, s. 17-27.

Ranking - inwestycje w infrastrukturę techniczna, 2014, „Wspólnota”, s. 4.

Sierak J., 2011, Zarzadzanie finansami jednostek samorzadu terytorialnego $w$ warunkach kryzysu, [w:] Owsiak S. (red.), Nowe zarzadzanie finansami publicznymi w warunkach kryzysu, PWE, Warszawa.

Sprawozdanie z działalności Regionalnych Izb Obrachunkowych i wykonania budżetu przez Jednostki Samorzadu Terytorialnego w 2005, 2008, 2009, 2010, 2011, 2012, 2013, 2014 roku, Krajowa Rada Regionalnych Izb Obrachunkowych, Warszawa 2006, 2009, 2010, 2011, 2012, 2013, 2014, 2015.

Ustawa z dnia 27 sierpnia 2009 r. o finansach publicznych, Dz. U., 2013, poz. 885 z późn. zm., art. 243.

Ustawa z dnia 5 czerwca 1998 r. o samorzadzie powiatowym, Dz. U., 2016.0.814.

\begin{abstract}
In recent years there was a series of negative economic trends related to the functioning of the local government sector in Poland. They concerned, among others, a decrease in revenues and increased debt levels. This article aims to identify the financial condition of selected city counties (cities with powiat rights). Particular attention was paid to the analysis of individual types of income and expenses of these units and the dynamics of their debt. The summary contains conclusions concerning the economic situation of selected cities.
\end{abstract}

\title{
Keywords
}

Cities on powiat status, local government budget, local finances. 